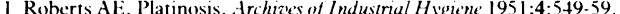

2 Industrial Injuries Advisory Council. Occupational asthma London: HMSO, 1981 (Cmnd 8121.

13 Dally MB, Hunter JV, Hughes EG, Stewart M. Newman Tavkor AJ. Hypersensitivity to platinum salts: a population studv. Am Rev Respir D 1980;121:230a.

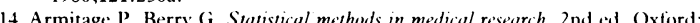
Blackwell, 1987:435-8.

15 Linnett PJ. Platinum salt sensitivity: a review of the health aspects of platinum refining in South Africa. Fournal of the Mine. Medical Officers Association of South Africa 1987;63(433):24-8. $1987 ; 42: 2+1-9$

17 Zetterstrom O, Nordvall SL, Bjorksten B, Ahlstedt S, Stelander M. Increased IgE antibody responses in rats exposed to tobacco smoke. 7 Allergy Clin Immunol 1985;75:594-8.
I8 Biagini RE, Meorman W'J, Lewis TR, Bernstein IL. Ozone enhancement of pla

a the experimentally ind Dis $1970: 102:+38-43$

20 Takafuji S, Suzuki S, Koizumi K, el al. Diesel-cxhaust particulates inoculated by the intranasal routc have an adjuvant activity for IgE production in mice. 7. Allergy Clin Immunol 1987;79:639-45.

21 Magnusson CGiM. Maternal smoking influences cord serum IgE and Ig1) levels and increases the risk for subsequent infant allergy. F. Allergy Clin Immunol 1986;78:898-9(1)4.

22 Chan-Ycung M, Lam S. Occupational asthma. Am Rev Respir Dis 1986;133 $686-703$

Accepted 2 August 1989
16 Holt P(i. Immune and inflammatory function in cigarette smokers. Thorax

\section{Acute and chronic arterial and venous effects of captopril in congestive cardiac failure}

\author{
S Capewell, D Taverner, W J Hannan, A L Muir
}

\section{Abstract}

Objective-To determine whether captopril alters peripheral venous tone in patients with congestive cardiac failure.

Design-Open study of patients at start of captopril treatment and three months later.

Setting-A hospital gamma camera laboratory.

Patients-16 Men with congestive cardiac failure in New York Heart Association class II or III, aged 57-73.

Interventions-Patients were initially given $500 \mu \mathrm{g}$ sublingual glyceryl trinitrate followed by $25 \mathrm{mg}$ oral captopril. The study was then repeated after three months' captopril treatment.

Main outcome measures-Previously validated non-invasive radionuclide techniques were used to measure changes in central haemodynamic variables and peripheral venous volumes in the calf.

Results-After $25 \mathrm{mg}$ captopril there were falls in blood pressure and relative systemic vascular resistance and increases in cardiac index and lef ventricular ejection fraction. This was accompanied by a $16 \%$ increase in peripheral venous volume $(95 \%$ confidence interval $13.4 \%$ to $18.4 \%, p<0.01$ ), which compared with an $11 \%$ increase after $500 \mu \mathrm{g}$ glyceryl trinitrate $(10 \%$ to $12 \%, \mathrm{p}<0.01)$. Eleven patients were restudied after three months' continuous treatment with captopril. The resting venous volume was higher than it had been initially, by about $10 \%$, and increased by a further $8.4 \%$ after $25 \mathrm{mg}$ captopril $(5 \cdot 4 \%$ to $11 \cdot 4 \%, \mathrm{p}<0.05)$.

Conclusions-Captopril is an important venodilator. Venous and arterial dilatation are produced short term and during long term treatment.
University Department of Medicine, Royal Infirmary, Edinburgh EH3 9YW $\mathrm{S}$ Capewell, MD, lecturer in medicine

D Taverner, MRCP, lecturer in medicine

W J Hannan, PHD, principal physicist

A L Muir, FRCP, reader in medicine

Correspondence to: Dr S Capewell, Department of Tuberculosis and Chest Diseases, Llandough Hospital, Penarth, South Glamorgan CF6 1XX.

Br Med f 1989;299:942-5 hydralazine. ${ }^{x y}$ Furthermore, reduced cardiac filling pressures persist during long term treatment with captopril. Although this has been attributed to venodilatation, ${ }^{2}$ it may simply reflect an improvement in ventricular diastolic performance. 'Studies of the venous response to captopril in heart failure are sparse and conflicting. Using venous occlusion plethysmography, Cowley et $a l^{10}$ and Awan et al observed that venous tone in the forearm fell within an hour after the first dose of captopril by $15 \%$ and $50 \%$ respectively. Faxon et al showed "a small rise" in the maximal venous volume in the calf after captopril, ${ }^{1 .}$ whereas Olivari et al found no significant changes." These studies assessed only the immediate effect of captopril, and there is no information about the venous changes after prolonged treatment. We therefore investigated the central and venous responses to captopril, comparing them with those after glyceryl trinitrate, a known venodilator, ${ }^{\prime}$ in patients with severe congestive cardiac failure at the start and after three months of captopril treatment.

\section{Methods}

Sixteen men with moderate or severe congestive cardiac failure secondary to ischaemic heart disease were studied at the start of captopril treatment; 11 were available for restudy after three months' treatment (table I). All 16 had symptoms and were in New York Heart Association class II or III, with impaired left ventricular function (mean left ventricular ejection fraction of $0 \cdot 19$ (table I)). They required daily frusemide at a mean dose of $116 \mathrm{mg}$.(range $80-160 \mathrm{mg}$ ), and four were also taking digoxin at a mean daily dose of $0.19 \mathrm{mg}$. The 11 men who were restudied had a mean age of 64 (range 57-73), were all in sinus rhythm, and had been clinically stable for at least one month before the study.

None of the patients suffered from more than occasional angina and none had received treatment with a vasodilator, such as long acting nitrates or calcium antagonists, within seven days before the study. Patients with severe hypertension or hypotension (systolic blood pressure $>180$ or $<90 \mathrm{~mm} \mathrm{Hg}$ ), who had had an acute myocardial infarction within three months and had clinically important liver, lung, renal, or cardiac valve disease were excluded. Five patients did not complete the study: two had a severe hypotensive reaction to the first dose and were not continued on captopril, and three started long term treatment but died one, two, and six weeks afterwards. Two deaths occurred at home, one being sudden and one being diagnosed clinically as due to an acute pressures fall, presumably indicating a reduction in preload. ${ }^{+}$This response resembles that observed after venodilators such as isosorbide dinitrate ${ }^{7}$ and sodium nitroprusside, ${ }^{8}$ rather than arterial vasodilators such as 
TABLE I-Clinical details of patients with congestive cardiac failure before captopril treatment

\begin{tabular}{|c|c|c|c|c|c|c|c|c|}
\hline $\begin{array}{c}\text { Case } \\
\text { No }\end{array}$ & Sex & $\begin{array}{c}\text { Age } \\
\text { (years) }\end{array}$ & $\begin{array}{l}\text { Body } \\
\text { surface } \\
\text { area } \\
\left(\mathrm{m}^{-}\right)\end{array}$ & $\begin{array}{l}\text { Daily } \\
\text { frusemide } \\
\text { dose } \\
\text { (mg) }\end{array}$ & $\begin{array}{c}\text { New York } \\
\text { Heart } \\
\text { Association } \\
\text { grade. }\end{array}$ & $\begin{array}{c}\text { Daily } \\
\text { digoxin } \\
\text { dose } \\
\text { (mg) }\end{array}$ & $\begin{array}{l}\text { Plasma } \\
\text { creatinine } \\
(\mu \mathrm{mol} / \mathrm{l})\end{array}$ & $\begin{array}{c}\text { Left } \\
\text { ventricular } \\
\text { ejection fraction }\end{array}$ \\
\hline 1 & $M$ & 62 & $1 \cdot 85$ & 80 & II & $0 \cdot 25$ & 99 & $0 \cdot 23$ \\
\hline 2 & $M$ & 63 & $1 \cdot 80$ & 120 & III & & 142 & $0 \cdot 11$ \\
\hline 3 & $M$ & 73 & 1.73 & 160 & III & $0 \cdot 125$ & 158 & $0 \cdot 20$ \\
\hline 4 & $M$ & 66 & 1.78 & 120 & II & & 108 & $0 \cdot 16$ \\
\hline 5 & M & 63 & 1.78 & 80 & III & & 138 & $0 \cdot 21$ \\
\hline 6 & $M$ & 63 & 1.96 & 160 & III & $0 \cdot 125$ & 131 & $0 \cdot 15$ \\
\hline 7 & $M$ & 57 & 1.73 & 120 & III & & 103 & $0 \cdot 09$ \\
\hline 8 & $M$ & 68 & 1.47 & 120 & III & & 186 & $0 \cdot 22$ \\
\hline 9 & $M$ & 69 & 1.97 & 120 & II & $0 \cdot 25$ & 125 & 0.43 \\
\hline 10 & $M$ & 62 & 1.87 & 160 & II & & 185 & $0 \cdot 11$ \\
\hline 11 & $M$ & 63 & $2 \cdot 02$ & 80 & III & & 114 & $0 \cdot 14$ \\
\hline Mean (SD) & & $64 \cdot 5$ & $1.81(0 \cdot 15)$ & $116(37 \cdot 7)$ & & $0 \cdot 19^{\star}$ & $135.4(30 \cdot 5)$ & $0.188(0.093)$ \\
\hline
\end{tabular}

${ }^{\star}$ In four patients.

myocardial infarction. The third patient died in hospital of progressive biventricular failure three weeks after starting captopril. These five patients were aged 63-70 and had slightly worse left ventricular function (mean $0 \cdot 15$, range $0 \cdot 09-0 \cdot 29$ ) than the 11 who completed the study, requiring a mean of $190 \mathrm{mg}$ frusemide daily, and four were in New York Heart Association class III or III to IV. Their results were therefore excluded from further analysis; apart from the greater fall in blood pressure their response to a single oral dose of captopril was in no way different from that of those who completed the study.

\section{MEASUREMENTS}

Heart rate was monitored from a continuous electrocardiogram, and blood pressure was measured with conventional sphygmomanometry (diastolic phase $\mathrm{V}$ ). The mean arterial blood pressure was calculated as diastolic blood pressure plus one third of the pulse pressure. The cardiac output was measured by rapidly injecting a bolus of autologous red cells labelled with technetium-99m $(750 \mathrm{MBq}),{ }^{1+}$ and the indicator dilution curve through the left ventricle was analysed. ${ }^{15}$ The total blood volume was derived from dilution of the radioisotope..$^{15}$ Left ventricular ejection fraction was measured with the electrocardiogramgated equilibrium blood pool method. ${ }^{1+}$ From each ventriculogram end diastolic counts corrected for physical decay and biological clearance of technetium were used to compute changes in end diastolic volume. Changes in stroke volume and end systolic volume were then calculated. ${ }^{1+16}$

Peripheral venous volume was measured with a scintillation probe positioned opposite the left calf. This consisted of a $4 \mathrm{~cm}$ diameter $\times 2 \mathrm{~cm}$ thick sodium iodide crystal coupled to a photo multiplier and positioned within a brass collimator. The detector was linked to a portable nucleonic system ( $J$ and $P$ Engineering, Reading, Model MS 310E) and printer (Epson MX80 FT3). The probe was positioned $50 \mathrm{~cm}$ lateral to the patient's left mid-calf, with a standard $7 \mathrm{~cm}$ length of calf defined by an arrangement of lead shields. The method assumes that the bulk of the blood volume in the calf is in the venous circulation. We had previously shown that venodilators such as glyceryl trinitrate cause an increase in the activity detected from the calf whereas arterial vasodilators such as hydralazine cause no change. ${ }^{\text {th }}$ Results from this method correlate closely with more traditional methods of venous plethysmography. ${ }^{17}$ is $T$ To assess the stability of this technique over a prolonged period eight other patients with congestive cardiac failure were studied with an identical protocol except that captopril was not given. The resting calf counts at the end of the two and a half hour period remained stable (mean $99 \cdot 5 \%$, range $96-105 \%$ of the starting values).

\section{STUDY PROTOCOL}

The same protocol was used for both initial and follow up studies. On the day of each study the patients omitted their usual diuretic and attended the hospital at $9 \mathrm{am}$ after a light breakfast. They rested for 30 minutes on a couch in a warm room with ambient temperature $22^{\circ} \mathrm{C}$ and then baseline central and peripheral haemodynamics were assessed. Patients were then given $500 \mu \mathrm{g}$ sublingual glyceryl trinitrate and the haemodynamic changes measured immediately after dissolution of the tablet, which took five to eight minutes. Previous studies suggest that values return to baseline well within 20 minutes. ${ }^{162}$ " At 20 minutes a $25 \mathrm{mg}$ tablet of captopril was given orally, and measurements were repeated 60 minutes later. Pulse, blood pressure, and venous volume were measured continuously. A further tablet of $500 \mu \mathrm{g}$ glyceryl trinitrate was then given sublingually, and after dissolution of the tablet a final set of all measurements was made 90 minutes after the oral captopril to assess any effects of combined treatment.

\section{FOLLOW UP CAPTOPRIL STUDY}

After completing the initial study patients were treated with captopril $25 \mathrm{mg}$ thrice daily with other drugs remaining unchanged. The patients were reviewed at monthly intervals. No changes in drugs were permitted apart from the dose of diuretic, which was altered if clinically indicated. After three months patients were restudied with the protocol described above, diuretics and captopril being omitted on that day. Angiotensin II and saline infusions were available to treat reactions to the first dose, but only saline was required in the two patients withdrawn from the study who experienced distinct hypotension.

\section{STATISTICAL METHODS}

Changes from baseline values during each study were analysed with analysis of variance. Student's $t$ test for paired comparisons was used to compare baseline data for the initial and follow up studies, and 95\% confidence intervals were calculated. The study protocol was approved by this hospital's ethical committee.

\section{Results}

\section{ACUTE HAEMODYNAMIC RESPONSES}

Glyceryl trinitrate-A $500 \mu \mathrm{g}$ tablet of glyceryl trinitrate produced modest and non-significant reductions in heart rate, blood pressure, and relative systemic vascular resistance (table II). The venous volume increased by $11 \%$ after glyceryl trinitrate ( $95 \%$ confidence interval $10 \%$ to $12 \%, \mathrm{p}<0.001$ ).

Captopril-Sixty minutes after captopril was given the mean arterial pressure had fallen by $16 \%$, the cardiac index had increased by $45 \%$, and the left ventricular ejection fraction had increased by $15 \%$. The relative systemic vascular resistance showed a corresponding fall of $42 \%(p<0 \cdot 01$, table II). The heart rate fell significantly whereas the left ventricular end diastolic volumes were little changed (table II). The venous volume in the calf had increased by $16 \%(13.4 \%$ to $18.4 \%$ ) 80 minutes after captopril (both $\mathrm{p}<0.01$ ). This increase in peripheral venous volume correlated significantly with the fall in mean arterial blood pressure $(r=0.54, p<0.05$, Spearman's rank correlation).

Glyceryl trinitrate after captopril-A further $500 \mu \mathrm{g}$ glyceryl trinitrate tablet taken sublingually 90 minutes after captopril produced no further significant changes in haemodynamic or venous variables (table III).

\section{HAEMODYNAMIC RESPONSES AFTER LONG TERM} CAPTOPRIL: BASELINE MEASUREMENTS

Eleven of the 16 patients were restudied after three months. Eight had improved by at least one New 


\begin{tabular}{|c|c|c|c|c|c|c|c|c|}
\hline \multirow[b]{2}{*}{ Measurement } & \multicolumn{2}{|c|}{ Baseline } & \multicolumn{2}{|c|}{ After glyceryl trinitrate } & \multicolumn{2}{|c|}{60 Minutes after captopril } & \multicolumn{2}{|c|}{$\begin{array}{c}90 \text { Minutes after captopril and } \\
\text { glyceryl trinitrate }\end{array}$} \\
\hline & Initial & Follow up & Initial & Follow up & Initial & Follow up & Initial & Follow up \\
\hline $\begin{array}{l}\text { Mean arterial blood pressure } \\
(\mathrm{mm} \mathrm{Hg})\end{array}$ & $105 \cdot 1(11 \cdot 6)$ & $103 \cdot 7(9 \cdot 5)$ & $102 \cdot 7(10 \cdot 3)$ & $99 \cdot 0(11 \cdot 0)$ & $88 \cdot 3(11 \cdot 3)^{\star}$ & $90 \cdot 2(13 \cdot 1)^{\star}$ & $88 \cdot 2(7 \cdot 4)^{\star}$ & $87.8(20.9)^{\star}$ \\
\hline $\begin{array}{l}\text { Cardiac index }(1 / \mathrm{min} / \mathrm{m} \\
\text { Sistemic vascular resistance }\end{array}$ & $1.95(0.53) \dagger$ & $2.57(0.66) \dagger$ & $2 \cdot 10(0 \cdot 54)$ & $2 \cdot 90(1 \cdot 18)$ & $2 \cdot 84(1 \cdot 35) \ddagger$ & $3 \cdot 24(1.09) \dagger$ & $2 \cdot 70(0.96) \dagger$ & $2 \cdot 89(1 \cdot 39)$ \\
\hline$(\mathrm{kPa} . \mathrm{s} / \mathrm{l})$ & $237 \cdot 5(81 \cdot 5) \dagger$ & $178.4(47.5) \dagger$ & $215 \cdot 6(66 \cdot 2)$ & $150 \cdot 9(54 \cdot 1)$ & $137 \cdot 4(58 \cdot 6)^{\star}$ & $123 \cdot 1(42 \cdot 7)^{\star}$ & $144 \cdot 3(57 \cdot 9)^{\star}$ & $143.0(46.8)^{\star}$ \\
\hline Stroke volume $(\mathrm{ml})$ & $43.6(15.8) \neq$ & $58.0(12.5) \neq$ & $45 \cdot 9(13 \cdot 0)$ & $64 \cdot 9(24 \cdot 2) \ddagger$ & $65 \cdot 7(30.5) \neq$ & $77 \cdot 5(25 \cdot 3)^{\star}$ & $62 \cdot 0(22 \cdot 7)$ 丮 & $65 \cdot 5(28 \cdot 9)$ \\
\hline End diastolic volume $(\mathrm{ml})$ & $262(113)$ & $268(116)$ & $251(118)$ & $259(159)$ & $338(167)$ & $334(182)$ & $311(146)$ & $290(191)$ \\
\hline $\begin{array}{l}\text { Left ventricular ejection } \\
\text { fraction }\end{array}$ & $0 \cdot 188(0.093)^{\star}$ & $0 \cdot 244(0 \cdot 138)^{\star}$ & $0 \cdot 215(0 \cdot 105)^{\star}$ & $0 \cdot 272(0 \cdot 160) \ddagger$ & $0.217(0.097) \ddagger$ & $\begin{array}{r}0.263(0.171) \\
76.5(1) \cdot 6+\end{array}$ & $\begin{array}{r}0.225(0 \cdot 108) \ddagger \\
80.5(9 \cdot 8)\end{array}$ & $0 \cdot 274(0 \cdot 198)$ \\
\hline Heart rate (beats/min) & $84 \cdot 9(12 \cdot 2)$ & $79 \cdot 8(14 \cdot 1)$ & $85 \cdot 4(9 \cdot 8)$ & $82 \cdot 6(10 \cdot 3)$ & $79 \cdot 9(10 \cdot 1) \ddagger$ & $76 \cdot 5(12 \cdot 6) \ddagger$ & $80 \cdot 5(9 \cdot 8)$ & $80 \cdot 0(11 \cdot 3)$ \\
\hline
\end{tabular}

${ }^{\star} \mathrm{p}<0 \cdot 01 . \neq \mathrm{p}<0 \cdot 02 . \neq \mathrm{p}<0 \cdot 05$

TABLE III-Peripheral venous volume after glyceryl trinitrate and captopril in initial and follow up studies. Mean (SD) values are expressed as percentages of baseline counts

\begin{tabular}{lll}
\hline & Initial study & Follow up stady \\
\hline $\begin{array}{l}\text { Baseline } \\
\text { After glyceryl trinitrate }\end{array}$ & $100(0 \cdot 5)$ & $100(0 \cdot 7)$ \\
80 Ninutes after captopril & $111 \cdot 0(1 \cdot 8)^{\star \star \star}$ & $108 \cdot 9(2 \cdot 3)^{\star \star}$ \\
$\begin{array}{c}\text { 90 Ninutes after captopril } \\
\text { and glyceryl trinitrate }\end{array}$ & $117 \cdot 9(4 \cdot 7)^{\star \star}$ & $108 \cdot 4(4 \cdot 5)^{\star}$ \\
\hline
\end{tabular}

${ }^{\star} \mathrm{p}<0.05,{ }^{\star \star} \mathrm{p}<0.01,{ }^{\star \star \star} \mathrm{p}<0.001$ Compared with baseline data on day of study.

York Heart Association class, and the median daily frusemide dose had also fallen considerably, from 120 to $80 \mathrm{mg}$. There were no other significant changes in clinical or laboratory variables. Before either glyceryl trinitrate or further captopril was given the 11 patients showed considerable improvements compared with their original baseline haemodynamic measurements. Although mean arterial pressure was unchanged, the cardiac index was $32 \%$ higher and the relative systemic vascular resistance had fallen by $25 \%(\mathrm{p}<0 \cdot 02)$. The left ventricular ejection fraction was significantly higher $(p<0.01)$, whereas the resting heart rate and left ventricular end diastolic volume were unchanged (table II). The peripheral venous volume (mean baseline calf counts) was $10 \cdot 2 \%$ higher.

\section{ACUTE RESPONSES TO GLYCERYL TRINITRATE AND} CAPTOPRIL AFTER LONG TERM CAPTOPRIL TREATMENT

The same study protocol was repeated after three months' captopril treatment.

Glyceryl trinitrate produced small increases in stroke volume and left ventricular ejection fraction. The falls in the mean arterial pressure and the relative systemic vascular resistance and the increase in cardiac index were again small and non-significant (table II). The venous volume in the calf increased by $9 \%(7 \cdot 4 \%$ to $10 \cdot 4 \%, p<0 \cdot 01$, table III) after glyceryl trinitrate treatment.

Captopril-The mean arterial pressure had fallen by $13 \% 60$ minutes after captopril treatment and the relative systemic vascular resistance by $31 \%$. The cardiac index showed a $26 \%$ increase and the stroke volume increased by $34 \%$ (table II). The venous volume had increased by $8 \cdot 4 \%(5 \cdot 4 \%$ to $11 \cdot 4 \%)$ 80 minutes after captopril treatment $(\mathrm{p}<0.05$, table III).

Glyceryl trinitrate after captopril-No significant changes in mean arterial pressure, left ventricular ejection fraction, and venous volumes were observed after the second tablet of glyceryl trinitrate (table II).

\section{Discussion}

This study confirms that the first dose of captopril produces a distinct and rapid reduction in afterload in patients with heart failure. ${ }^{1-4}$ Mean arterial pressure and relative systemic vascular resistance fell in the short term by $16 \%$ and $42 \%$ respectively', and the cardiac index increased by $45 \%$. After three months, though the cardiac index was higher and relative systemic vascular resistance lower, further captopril caused additional short term improvement. Similar benefits have been reported in several placebo controlled studies with captopril ${ }^{12}$ and also enalapril. ${ }^{421}$ These studies also showed short and long term reductions in right atrial pressure, pulmonary capillary wedge pressure, and left ventricular end diastolic pressures, ${ }^{12+}$ taken to represent a venodilative effect. Our study confirmed that there is short term venodilatation after captopril treatment for heart failure. Glyceryl trinitrate acts predominantly as a venodilator, reducing preload with little effect on afterload. ${ }^{9}{ }^{1620}$ Furthermore, the venodilatation produced by glyceryl trinitrate is transient and complete after about 20 minutes. ${ }^{16} 20$ We were therefore able to compare the haemodynamic responses to captopril with the baseline values.

Captopril produced distinct venodilatation in patients with heart failure with an increase in venous volume of $16 \%$, half as much again as glyceryl trinitrate at a dose of $500 \mu \mathrm{g}$. This increase with captopril corresponds to physical venous occlusion with a sphygmomanometer thigh cuff inflated to $20 \mathrm{~mm} \mathrm{Hg},{ }^{19}$ which is analogous to the traditional treatment for heart failure: rotating venous tourniquets on the arms and legs."?

Our study also suggests that there is chronic venodilatation in patients with heart failure given long term captopril. This had long been suspected because of the persistent reduction in variables of preload without significant changes in total blood volume. ${ }^{2323}$ Our measurements were made from differences in individual calf counts between the first and second studies, corrected for injected dose and precordial counts. A degree of persistent venodilatation would explain why the short term responses in venous volume to captopril were fairly blunted in our follow up study (an increase of $8 \% v 16 \%$ ) in contrast with those to glyceryl trinitrate, which still produced a short term increase of $9 \%$, similar to the $11 \%$ in the short term study. This chronic venodilatation with captopril was not due to an increase in total blood volume, which was unchanged in our study and may sometimes fall with long term treatment. ${ }^{2}$

When glyceryl trinitrate was given after captopril in either study there was little further increase in venous volume. This may be because glyceryl trinitrate and captopril have a common mechanism of venous action or because of rapid venous tachyphylaxis to glyceryl trinitrate. Alternatively, there may be a finite limit to the venodilatation that is achievable by pharmacological, as opposed to physical, means. Nitrates cause venodilatation by a direct effect on the venous smooth muscle cell, probably mediated by endothelial derived relaxing factor. ${ }^{2+25}$ The mechanism of venodilatation after captopril remains unclear. Venous tone is consistently increased in patients with congestive cardiac failure. ${ }^{41017}$ Several mechanisms have been 
implicated including the renin-angiotensin system, the sympathetic nervous system, prostaglandins, kinins, and vasopressin. ${ }^{26.28}$ Angiotensin II concentrations are increased in congestive cardiac failure and fall distinctly with captopril.' Angiotensin II is a potent constrictor of arteries and to a lesser extent veins. ${ }^{24}{ }^{311}$ It also modulates the sympathetic nervous system, and a fall in concentrations should reduce sympathetic nervous activity. ${ }^{3.1}$ Noradrenaline concentrations are usually increased in congestive cardiac failure and fall after captopril treatment."

Venodilatation with captopril may have considerable clinical importance. Profound hypotensive reactions sometimes occur when treatment with angiotensin converting enzyme inhibitor is started (the first dose reaction). ${ }^{2}$ These are more easily explained by a rapid pooling of blood volume in the venous circulation. A similar reaction may follow initiation of prazosin treatment, also a potent venodilator." Similarly, postural hypotension may occur acutely or after long term inhibition of angiotensin converting enzyme and again suggests considerable venodilatation, as previously described with prazosin. The postural drop in blood pressure with captopril is usually asymptomatic, perhaps because cerebral blood flow is maintained or even increased. ${ }^{3 .}$

Venodilatation and the associated reduction in cardiac preload may also improve survival. Although short term haemodynamic "benefits" have been described in patients with cardiac failure treated with a variety of arterial vasodilators including hydralazine and minoxidil, long term benefits are minimal. ${ }^{33}$ Only angiotensin converting enzyme inhibitors and a nitrate-hydralazine combination have produced significant increases in survival; both have a venodilative action. ${ }^{524}$

In conclusion, our data suggest that captopril produces considerable venodilatation in addition to arterial vasodilatation and that this occurs both short term and after three months' treatment.

We thank Miss F Taddei and Miss S Turnbull for their excellent technical help; Mr A Millar for help with radiopharmaceuticals; and Mrs V Campbell for typing the manuscript.

1 Captopril Multicentre Rescarch Group. A placebo controlled trial of captopril in the management of refractory heart failure. $\mathcal{F} \mathrm{Am}$ Coll Cardiol 1983;2 755-63.

2 Cleland JGF, Dargie HJ, Hodsman GP, $e t$ al. Captopril in heart failure. A double blind controlled trial. Br Hearı f 1984;52:530-5.

3 Packer $M$. Converting enzyme inhibition for severe chronic heart failure: views from a skeptic. Int f Cardiol 1985;7:111-20.

+ Packer M, Lee WH, Yushak M, Medina N. Comparison of captopril and enalapril in patients with severe chronic heart failure. $N$ Engl f Med 1986;315:8+7-53.

5 Consensus Trial Study Group. Effects of enalapril on mortality in severe congestive heart failure. N Engl f Med 1987;316:1+29-35.
6 Furburg CD, Yusuf S. Effect of vasodilators on survival in chronic heart failure. Am f Cardiol 1985;55:1110-3.

7 Leier CV, Huss P, Magorien RD, Unverferth DV. Improved exercise capacity and differing arterial and venous tolerance during chronic isosorbide dinitrate theraps for congestive heart failure. Circulation 1983:67:817-22.

8 Franciosa JA, Pierpont G, Cohn JN. Hemodynamic improvement after oral hydralazine in left ventricular failure. A comparison with nitroprusside infusion in 16 patients. Ann Intern Med 1977:86:388-93.

9 Miller RR, Fennel WH, Young JB, Palomo AR, Quinones MA. Differential sistemic arterial and venous actions and consequent cardiac effects of vasodilator drugs. Prog Cardiozusc Dis 1982;24:353-74.

10 Cowley AJ, Rowley JM, Stanner KL, Hampton JR. Captopril therapy for heart failure: a placebo controlled studv. Lancet 1982;ii:730-2.

11 Awan NA, Evenson MK, Needham KE, $W^{\prime}$ in A, Mason DT. Efficacy of oral angiotensin converting enzyme inhibition with captopril therapy in severe chronic normotensive congestive heart failure. Am Heurl f 1981;101:22-31.

12 Faxon DP, Halperin JL, Creager MA, Gavras H, Schick EC, Ryan T Angiotensin inhibition in severe heart failure: acute central and limb hemodynamic effects of captopril with observations on sustained oral therapy. A $m$ Heart f 1981;101:548-56.

13 Olivari MT, Levine TB, Cox T, Cohn JN. Contrasting capacitance effects of captopril and nitroglvcerin in congestive heart failure. Circulation 1982: 66 ( suppl II): 209

1t Hannan WJ, Vojacek J, Dewhurst NG, Muir AL. The sequential measurement of ventricular volumes and cardiac output by radionuclide. Clin Phys Physiol Meas 1980;1:125-31.

15 Millar AM Wathen CG, Muir AL. Failure in labelling of red blood cells with re: interaction hetween intravenous cannulac and stanneus perophosphate. Eur 7 Nucl Med 1983:8:502-4.

16 Wathen CG. Hannan WJ. Adie CJ, Muir AL A radionuclide method for the simultaneous study of the effects of drugs on central and peripheral hacmod namics. Brf Clin Phurnucol 1983:16:+5-50.

17 Rothe CF. Venous system: physiology of the capacitance vessels. In: Handbook of physiology. Section II, vol III, part 1. Peripheral circulation. Bethesda: American Physiological Society, 1983:+27-8.

18 Rutlen DL, Wackers FJT, Zaret BL. Radionuclide assessment of peripheral intravascular capacity: a technique to measure intra-vascular rolume changes in the capacitance circulation in man. Circulation 1981;64:146-52.

19 Wathen CG. Hannan WJ, Adie CJ, Muir AL. Changes in venous compliance and arterial tone assessed by radionuclide methods. Eur $\mathrm{f} \mathrm{Nucl}$. Med 1983;6: $\mathrm{A} 12$.

20 Lefkowitz $\mathrm{CA}$, Gordon WM, Armstrong PW. A comparative evaluation of hemodynamic and neurohumeral effects of nitroglecerine and nifedipine in congestive heart failure tmeral curdiol 1987:59:59-63B.

21 Cletand JGF, Dargie HJ, Ball SG, $e t$ al. Effects of enalapril in heart failure: a double blind study of effects of exercise performance, renal function, hormones and metabolic state. Br Heart f 1985:54:305-12.

$22 \mathrm{McMichacl} \mathrm{J}$, Shafer EPS. The action of intravenous digoxin in man. (O F Med 1944:37:123-35.

23 Fouad FM, Tarazi RC, Bravo EL, Hart NJ, Castle LW, Salcedo EE. Long term control of congestive heart failure with captopril. Am $\mathcal{I}$ Cardiol $1982 ; 49: 1+89-96$

24 Cohn JN, Archibald DG, Ziesche S, et al. Effect of vasodilator therapy on mortality in chronic congestive heart failure. $N$ lingl 7 . Med 1986;314: $15+7-52$

25 Anonrmous. EDRF [Editorial]. Lancet 1987; ii: 137-8.

26 Johnston CI, Clappison BH, Anderson WP, Yasujima M. Effect of angiotensin converting enzame inhibition on circulating and local kinin levels. A $m$. Cardiol 1982:49:1+101-t.

27 Zusman RM. Renin and non-renin mediated antihypertensive action of conerting encme inhibitors. Kidne' Im 1984:25:969-83.

28 Reigger (idJ, Kochsick K. Vasopressin, renin and norepinephrine levels before and after captopril administration in patients with congestive heart failure due to idiopathic dilated cardiomsopathy. $t m$ f Cordol 1986;58: failure

29 Dollery CT, Hill DW, Hodge JV. The response of normal retinal blood vessels to angiotensin and noradrenaline. F Phvsiol (Lond) 1963;165:500-7.

30 De Pascale NP, Burch GE. Effect of angiotensin II on the intact forearm veins of man. Circ Res 1963:13:239-4

31 Siedelin PH, Coutic $\mathrm{W}^{\prime}$, Struthers AD). The effect of angiotensin II on noradrenaline release in man. Br f Clin Pharmacol 1987;24:261 A.

32 Paulson OB. Converting enzeme inhibition resets cercebral autoregulation at lower blood pressure. F Hypertens 1985;3 (suppl 3: :487-8.

33 Lipkin DP, Poole-W'ilson PA. Treatment of chronic heart failure: a review of recent drug trials. Br.Med 7 1985;291:993-6.

Accepled 7 August 1989
The case of the bankruptcy of Dr. C. F. Knight was before the Dublin Court recently. In the course of the hearing Dr. Knight produced a letter removing him from "his office on the Medical Board" of Mercer's Hospital, to which he is physician. It further appeared that he had paid $£ 1,400$ for his position, $£ 1,100$ of which he believed passed to his predecessor, and $£ 300$ to an improvement fund. An indignant correspondent calls our attention to this custom of purchase which exists in some Dublin hospitals, and which may exist elsewhere, although the public do not know of it. He refers to an exposure which appeared in the JoURNAL, in reference to purchase in the Meath Hospital. We are informed that the practice is openly recognised in the City of Dublin Hospital, Mercer's, and Jervis Street; is believed to exist in the Adelaide; and has occurred in the Meath. The other hospitals are, so far as the public know, free from what must be considered a grave blemish, in any circumstances. In Dublin it is one of the unfortunate results which follow there, as elsewhere, the starting of unneeded hospitals by medical men. A sort of company is formed, money is advanced, and it is expected that this money shall be as realisable as if it were invested in any commercial undertaking. But it leads to many abuses. Frequently a man is, it is said, appointed not because he is an able man, but because he can help to swell the income, and can pay money for the office. Some persons have been found to defend the practice. Sir Dominic Corrigan was in favour of it. But the late Commission on Dublin Hospitals condemned it in severe terms. Undoubtedly it ought not to exist, and it is fair to say that in the City of Dublin Hospital it is being wiped out. The most brilliant candidate may be excluded because he has not a well-filled purse, and a stupid mediocrity may be appointed over his head. We do not say that these things do occur in practice, but they are possible. If the public, however, would exercise some discrimination in their aid-giving, we should have fewer mushroom hospitals throughout the three countries, and we should soon have an en of a system which makes purchase possible. (British Medical fournal $1889 ; \mathrm{i}: 793$ 